\title{
Professional and Pedagogical Competence of Early Childhood Education Teachers in Millenial Era
}

\author{
Erick Yolanda
}

Padang State University, Padang - Indonesia, erickyolanda@gmail.com

\begin{abstract}
This research is based on current problems that occur in kindergarten teachers in Pariangan DistrictThis research is a quantitative study using descriptive methods with ex post facto research design on the subject of research namely kindergarten teachers in Pariangan sub-district. The data collection technique in this study was a questionnaire, then the data analysis used was a descriptive statistical test. The results showed that the description of the professional competence of kindergarten teachers in the millennial era was already in the high category of $74.26 \%$. And the kindergarten teachers pedagogical competence in this millennial era in the Pariangan sub-district is already in the high category of $76.92 \%$, but the indicators of taking reflective, corrective and innovative actions in improving the quality of the process and the results of early childhood development need to be increased again because they are in the category just $51 \%$.
\end{abstract}

Keywords: early childhood education, teacher, professional, pedagogical, competence, millennial era.

\section{INTRODUCTION}

Early childhood education has a very important role in developing and optimizing the potential that children have. Early childhood education is one of the coaching efforts aimed at children from birth to the age of six years which is carried out through the provision of educational stimuli to help physical and spiritual growth and development so that children have readiness to enter further education.

Early childhood is defined by the National Association for Education of Young Children (NAEYC) as children aged 0-8 years. NAEYC divides early childhood into 0-3 years, 3-5 years, and 6-8 years (Brewer, 2007). According to this definition early childhood is a group of people who are in the process of growth and development. Early childhood is a unique individual who has a pattern of growth and physical development, cognitive, socioemotional, creativity, language and communication that are specific to the stages being passed by the child (Suryana, 2016). Meanwhile, according to Law No. 20 of 2003 said that early childhood is children aged 0 to 6 years.

According to Nurmalitasari (2015) early childhood are children whose age has not yet entered formal educational institutions such as elementary schools (SD) and they usually stay at home and participate in activities in pre-school educational institutions, such as play groups, kindergartens or parks childcare. With the technological advances of children who are in this millennial era need to get sufficient stimulation from an early age in every aspect of their development, one of the most important role in implementing it is the teacher (Novianti, Puspitasari, \& Chairilsyah, 2013) .

Kindergarten (TK) is the second educational institution for children after family. School responsibility does not only equip students with a number of knowledge, but also is responsible for fostering and developing aspects of child development in accordance with the stages of development. According to Sofyan Willis (in Risaldy \& Meity, 2015) the emergence of behavioral disorders among students comes from teachers as education implementers and educational support facilities that are needed by students.

Teachers in carrying out their duties should understand students. Teachers' understanding of students is not only related to learning material, but rather to the growth and development of children. Development is a change, and this change is not quantitative, but qualitative. Developments are not emphasized on the material side but on the functional side (Mayar, 2013) .

As a professional teacher of course, an educator must have more potential to be able to facilitate students in learning that is known as pedagogical competence. And also an ability possessed by an educator about mastering the learning material of students widely and to enable them to guide students in meeting established standards known as professional competence. With the mastery of some of the competencies above will certainly have an impact on optimal child development so that the goal of early childhood education is achieved, namely optimization in every aspect of child development.

Republic of Indonesia Government Regulation number 19 of 2015 concerning National Education 
Standards explains that competencies that must be possessed by an educator include pedagogical, personality, social, and professional competencies. The four competencies are integrated in the performance of an educator.

According to Priansa (2014) teacher professional competence is the ability of teachers to master knowledge in the fields of science and technology, arts and culture related to their scientific fields. Meanwhile, according to Surya (in Kunandar, 2007) professional teachers will be reflected in carrying out the dedication of tasks marked by expertise in both the material and method. In addition, it is also demonstrated through his responsibilities in carrying out all his services. Professional teachers should be able to assume and carry out responsibilities as a teacher to students, parents, society, nation, state, and religion. Professional competence is the ability, expertise, basic skills of educators who must be mastered in carrying out their duties as a teacher.

Standards competency are stated by the National Association of Education for Young Childrens (NAEYC) (in Mariyana, 2010) as follows:

1) Supports children's development and learning:

a) Know and understand the characteristics and needs of children.

b) Knowing and understanding various things that affect development and learning.

c) Use knowledge about development to create a healthy, supportive, and challenging learning environment.

2) Build relationships with families and communities:

a) Know and understand the characteristics of family and society.

b) Supporting and empowering the family and community through mutual respect and reciprocity.

c) Involves family and community in the development and learning of children.

3) Observe, document, and assess:

a) Understand the purpose, benefits and usefulness of the assessment;

b) Use appropriate observations, documentation, and other assessment tools and approaches.

c) Understand and practice judgments that can be accounted for in partnership with family and other professions.

4) Teaching and learning:

a) Liaise with children and family;

b) Use a developmentally oriented approach that is appropriate.

c) Understanding knowledge in the field of early childhood education; and

d) Develop a meaningful curriculum.

5) Become a professional:

a) Identifying and engaging in the area of early childhood.

b) Know and uphold the ethical standards and values of other professions.

c) Using continuity, collaborative learning in the teaching practices displayed. d) Integrate knowledge, reflection, and critical perspective in early childhood education. and

e) Give attention in telling advice to children and the profession.

The professional competencies and professional competencies of kindergarten teachers as stipulated in PERMENDIKBUD Number 137 of 2014 attachment II concerning kindergarten teacher professional competency standards are as follows:

a. Develop material, structure, and concepts in scientific fields that support and are in line with the needs and stages of early childhood development.

The Sub Competencies are:

1) Examining the basic concepts of science in the fields of mathematics, science, language, social studies, arts and religion in accordance with the needs, stages of development and psychomotor early childhood

2) Organizing basic scientific concepts as tools, activities and content in early childhood development

b. Designing various creative development activities in accordance with the stages of early childhood development.

The Sub Competencies are:

1) Formulate the objectives of each development activity

2) Analyzing early childhood development in each area of development

3) Select materials for various development activities according to the level of early childhood development

4) Organizing creative development activities according to the level of early childhood development

c. Develop professionalism in a sustainable manner by taking reflective action.

The Sub Competencies are:

1) Reflect on one's own performance continuously

2) Utilizing the results of reflection in order to increase professionalism.

The scope of pedagogical competencies according

to Janawi (2011) includes: first, mastering the characteristics of students. second, mastering the theories and principles of learning. third, developing curriculum and educational design that educates, utilizing Special Instrucional Objectives (ICT) for the benefit of learning. fifth, facilitating the development of potential learners. sixth, communicate effectively, empathically and politely with students. seventh, conduct evaluation and assessment of learning processes and outcomes. eighth, utilize the results of the evaluation and evaluation process and learning outcomes for the benefit of learning. ninth, take reflective actions to improve the quality of learning. This ability will determine the success of the teacher in carrying out the learning process.

Based on the regulation of the Minister of Education and Culture of the Republic of Indonesia 
number 137 of 2014 concerning national standards for early childhood education in Appendix II explains the pedagogical competency standards and pedagogical sub competencies of kindergarten teachers including:

a) Organizing aspects of development according to the characteristics of early childhood.

Sub competencies include:

1) Examine aspects of development according to the characteristics of early childhood

2) Classifying early childhood according to needs on various aspects of development

3) Identifying early childhood abilities in various development fields

4) Identifying the difficulties of young children in the various fields of Development

b) Analyze play theory according to aspects and stages of development, needs, potential, talents, and interests of early childhood.

Sub competencies include:

1) Understanding various learning theories and principles of educational learning while playing related to various fields of development in PAUD

2) Examining learning theories in the context of play and learning that are appropriate to the needs of aspects of early childhood development

3) Applying a variety of approaches, strategies, methods, and techniques while playing and learning that are holistic, according to the needs of early childhood, and meaningful, related to various fields of development in PAUD

4) Designing play activities as a form of learning that educates young children

c) Design early childhood development activities based on the curriculum.

Sub competencies include:

1) Compile the contents of the child development program in accordance with the themes and needs of early childhood on various aspects of development

2) Creating a play activity plan in the form of an annual, semester, weekly and daily program

d) Carry out educational development activities.

Sub competencies include:

1) Choose the principles of development that are educational and fun

2) Designing development activities that are educational and complete, both for activities in the classroom, and outside the classroom

3) Implement play activities that are holistic, authentic, and meaningful

e) Utilizing technology, information and communication for the benefit of conducting educational development activities.

Sub competencies include:

1) Choosing information and communication technology and teaching materials that are suitable for early childhood development activities.
2) Using information and communication technology to improve the quality of educational development activities

f) Developing the potential of early childhood for selfactualization.

Sub competencies include:

1) Selecting activity facilities and learning resources for early childhood development

2) Making media for early childhood development activities

3) Developing the potential and creativity of early childhood through play activities while learning

g) Communicate effectively, empathically, and politely.

Sub competencies include:

1) Choose various effective, empathic and polite communication strategies with young children

2) Communicate effectively, empathically, and politely with early childhood

h) Organizing and making assessment reports, evaluating early childhood learning processes and outcomes.

Sub competencies include:

1) Understand the principles of assessment and evaluation of early childhood learning processes and outcomes

i) Determine the scope of the objectives of the assessment process and learning outcomes in early childhood.

Sub competencies include:

1) Selecting approaches, methods and techniques for assessment of processes and results of development activities in early childhood

2) Using the principles and procedures for the assessment of the process and results of early childhood development activities

3) Administer the assessment of the learning process and learning outcomes on an ongoing basis by using various instruments

4) Determine the level of achievement of early childhood development

5) Analyze the results of the assessment process and learning outcomes for various purposes

6) Evaluate the learning process and results

j) Using the results of the assessment, development and evaluation of programs for the benefit of early childhood development.

Sub competencies include:

1) Using information on the results of assessments and evaluations for the continuity of early childhood learning

2) Carry out remedial and enrichment programs

3) Utilizing information on learning assessment and evaluation results to improve the quality of learning

4) Communicating the results of the development assessment and program evaluation to stakeholders 
k) Perform reflective, corrective and innovative actions in improving the quality of the processes and results of early childhood development.

Sub competencies include:

1) Conduct a reflection of the development activities of children aged early that have been implemented

2) Improve the quality of early childhood development through classroom action research

3) Conduct classroom action research.

\section{RESEARCH METHODS}

This research is a descriptive study using a quantitative approach. This study aims to explain the phenomenon that exists by using numbers to describe the characteristics of individuals or groups (Syamsudin \& Damiyanti: 2011). This study assesses the nature of the conditions that appear. The objectives in this study are limited to describe 1 . professional competence of kindergarten teachers in Pariangan District and 2. pedagogical competence of kindergarten teachers in Pariangan District, Tanah Datar District.

\section{RESEARCH RESULTS AND DISCUSSION}

This section discusses the results of research on professional competence and pedagogical competence of Kindergarten teachers in the Pariangan sub-district, Tanah Datar district. The research data was obtained through administrating the instruments as many as 23 kindergarten teachers in the Pariangan sub-district, Tanah Datar district.

Table 1. Level of Respondents' Achievement for each Kindergarten Teacher Professional Competency indicator

\begin{tabular}{|l|c|c|c|c|}
\hline \multicolumn{1}{|c|}{ Indicator } & $\begin{array}{c}\text { Ideal } \\
\text { Score }\end{array}$ & Average & $\begin{array}{c}\text { \% Achievement } \\
\text { Rate }\end{array}$ & Category \\
\hline $\begin{array}{l}\text { Develop material, structure, and concepts in scientific fields that } \\
\text { support and are in line with the needs and stages of early childhood } \\
\text { development, }\end{array}$ & 40 & 32.26 & 80.65 & High \\
\hline $\begin{array}{l}\text { Designing various creative development activities in accordance with } \\
\text { the stages of early childhood development }\end{array}$ & 50 & 34.35 & 68.70 & High \\
\hline $\begin{array}{l}\text { Develop professionalism in a sustainable manner by taking reflective } \\
\text { action }\end{array}$ & 40 & 29.57 & 73.93 & High \\
\hline Ideal Total Score for Kindergarten Teacher Professional Competence & 130 & 207.4 & 74.26 & High \\
\hline
\end{tabular}

Table 2. Level of Respondents' Achievement for each Kindergarten Teacher's Pedagogical Competency indicator

\begin{tabular}{|l|c|c|c|c|}
\hline \multicolumn{1}{|c|}{ Indicator } & $\begin{array}{c}\text { Ideal } \\
\text { Score }\end{array}$ & Average & $\begin{array}{c}\text { \% Achievement } \\
\text { Rate }\end{array}$ & Category \\
\hline $\begin{array}{l}\text { Organizing aspects of development according to the characteristics } \\
\text { of early childhood }\end{array}$ & 20 & $4: 30$ & 81.50 & Very high \\
\hline $\begin{array}{l}\text { Analyzing play theory according to aspects and stages of } \\
\text { development, needs, potential, talents, and interests of early } \\
\text { childhood }\end{array}$ & 20 & 16.09 & 80.45 & High \\
\hline $\begin{array}{l}\text { Design early childhood development activities based on the } \\
\text { curriculum }\end{array}$ & 35 & 29.30 & 83.71 & High \\
\hline Carry out development activities that educate .. & 15 & 12.00 & 80.00 & High \\
\hline $\begin{array}{l}\text { Utilizing information and communication technology for the benefit } \\
\text { of organizing educational development activities }\end{array}$ & 10 & 7.78 & 77.80 & High \\
\hline Developing the potential of early childhood for self-actualization. & 15 & 11.91 & 79.40 & High \\
\hline Communicate effectively, empathically, and politely & 10 & 8.04 & 80.40 & High \\
\hline $\begin{array}{l}\text { Organizing and making assessment reports, evaluating early } \\
\text { childhood learning processes and outcomes }\end{array}$ & 20 & 15.78 & 78.90 & High \\
\hline $\begin{array}{l}\text { Determine the scope of the target assessment of the process and } \\
\text { learning outcomes in early childhood }\end{array}$ & 30 & 22.61 & 75.37 & High \\
\hline $\begin{array}{l}\text { Use the results of assessment, development and evaluation of } \\
\text { programs for the benefit of early childhood development. }\end{array}$ & 20 & 15.52 & 77.60 & High \\
\hline $\begin{array}{l}\text { Perform reflective, corrective and innovative actions in } \\
\text { improving the quality of the processes and results of early } \\
\text { childhood development. }\end{array}$ & 15 & 7.65 & 51.00 & Enough \\
\hline $\begin{array}{l}\text { Ideal Total Score for Kindergarten Teacher Professional } \\
\text { Competence }\end{array}$ & 210 & 162.98 & 76.92 & High \\
\hline
\end{tabular}




\section{A. Kindergarten Teacher professional competence}

A description of the professional competencies of kindergarten teachers throughout Pariangan, in Table 1 below. the results of the analysis of the level of achievement of each indicator of professional competence of kindergarten teachers are presented in table 1.

In table 1 in general the level of achievement of professional competency scores for kindergarten teachers in Pariangan sub-district with a score of $74.26 \%$ of the ideal score. It is seen that the highest achievement indicator is $80.65 \%$ on the indicator of developing material, structure, and scientific field concepts that support and are in line with the needs and stages of early childhood development with a high category. Overall indicators of professional competence for kindergarten teachers are in the high category.

In table 2 in general the level of achievement of the professional competency scores of kindergarten teachers in the Pariangan sub-district with a score of 76.92 $\%$ of the ideal score. It appears that the highest achievement indicator $81.50 \%$ on the indicator organizes aspects of development in accordance with the characteristics of early childhood with a very high category. The lowest achievement level of $51.00 \%$ on the indicator of taking reflective, corrective and innovative actions in improving the quality of the process and the results of early childhood development with sufficient categories. Overall indicators of professional competence for kindergarten teachers are in the high category.

\section{CONCLUSION}

In facing challenges in the digital era (millennial era) teachers must be able to follow these developments. Because of the increasingly technological and technological development of course will also have an impact on the development of teacher competence. For example, professional competence and pedagogical competence. The results showed that the description of the professional competence of kindergarten teachers in the millennial era was already in the high category of $74.26 \%$. And the kindergarten teacher's pedagogical competence in this millennial era in the Pariangan sub-district is already in the high category of $76.92 \%$, but the indicators of taking reflective, corrective and innovative actions in improving the quality of the process and the results of early childhood development need to be increased again because they are in the category just $51 \%$.

\section{REFERENCES}

[1] Brewer, J. A. (2007). Introduction to Early Childhood Education: Preschool through primary grades. USA: Pearson Education, nc.

[2] Janawi. (2011). Kompetensi Guru "Citra Guru Profesional.” Bandung: Alfabeta.

[3] Kunandar. (2007). Guru Profesional Implementasi Kurikulum Tingkat Satuan Pendidikan dan Sukses dalam Sertifikasi Guru. Jakarta: Raja Grafindo Persada.

[4] Majid, A. (2008). Perencanaan Pembelajaran. Bandung: Remaja Rosda Karya.

[5] Mariyana, R. (2010). Pengelolaan Lingkungan Belajar. Jakarta: Prenada Media Group.

[6] Mayar, F. (2013). Perkembangan Sosial Anak Usia Dini Sebagai Bibit untuk Masa Depan Bangsa. AlTa'lim, 1(6), 459-464.

[7] Mulyasa, E. (2013). Standar Kompetensi dan Sertifikasi Guru (Tujuh). Bandung: Remaja Rosda Karya.

[8] Novianti, R., Puspitasari, E., \& Chairilsyah, D. (2013). Pemetaan Kemampuan Guru Paud Dalam Melaksanakan Asesmen Perkembangan Anak Usia Dini di Kota Pekanbaru. Sorot, 8(1), 95-104.

[9] Nurmalitasari, F. (2015). Perkembangan Sosial Emosi pada Anak Usia Prasekolah. Buletin Psikologi, 23(2), 103-111.

[10] Priansa. (2014). Kinerja dan Profesionalisme Guru. Bandung: Alfabeta.

[11] Risaldy, S., \& Meity, H. I. (2015). Panduan Mengatasi Permasalahan Anak Usia Dini. Jakarta: PT. Luxima Metro Media.

[12] Suryana, D. (2016). Pendidikan Anak Usia Dini Stimulasi dan Aspek Perkembangan Anak (1st ed.). Jakarta: Kencana.

[13] Yamin, M., \& Sanan, S. J. (2013). Panduan PAUD. Ciputat: Gaung Persada Press Group. 